\title{
Dietary behaviour and competition for vegetal resources in two Early Miocene pecoran ruminants from Central Spain
}

\author{
Daniel DEMIGUEL \\ Universidad de Zaragoza, Departamento de Ciencias de la Tierra, \\ Instituto Universitario de investigación en Ciencias Ambientales de Aragón (IUCA), \\ Pedro Cerbuna 12, E-50009 Zaragoza (Spain) \\ and Institut Català de Paleontologia Miquel Crusafont (ICP), \\ Universitat Autònoma de Barcelona, \\ Campus de la UAB s/n, 08193 Cerdanyola del Vallès, Barcelona (Spain) \\ daniel.demiguel@icp.cat \\ Victoria QUIRALTE \\ Museo Nacional de Ciencias Naturales, Departamento de Paleobiología, \\ CSIC, José Gutiérrez Abascal 2, E-28006 Madrid (Spain) \\ Beatriz AZANZA \\ Universidad de Zaragoza, Departamento de Ciencias de la Tierra, \\ Instituto Universitario de investigación en Ciencias Ambientales de Aragón (IUCA), \\ Pedro Cerbuna 12, E-50009 Zaragoza (Spain) \\ Plinio MONTOYA \\ Universitat de València, Departamento de Geología, \\ Doctor Moliner 50, E-46100 Burjassot (Spain) \\ Jorge MORALES \\ Museo Nacional de Ciencias Naturales, Departamento de Paleobiología, \\ CSIC, José Gutiérrez Abascal 2, E-28006 Madrid (Spain)
}

DeMiguel D., Quiralte V., Azanza B., Montoya P. \& Morales J. 2012. - Dietary behaviour and competition for vegetal resources in two Early Miocene pecoran ruminants from Central Spain. Geodiversitas 34 (2): 425-443. http://dx.doi.org/10.5252/g2012n2a10

\begin{abstract}
Dietary behaviour and competition for resources are investigated for the small-sized ruminants Andegameryx Ginsburg, 1971 and Procervulus Gaudry, 1877 representatives of two largely distinct states of diversification of pecorans. Results obtained from dental microwear and mesowear methodologies are concordant with a mixed feeder strategy for the taxa from the Early Miocene environments of the Iberian Chain (Central Spain). Further, the Spanish taxa investigated had less abrasive diets
\end{abstract}




\section{KEY WORDS \\ Ruminantia, \\ Andegameryx, \\ Procervulus, \\ microwear, \\ mesowear, \\ paleodiet, \\ paleoecology.}

MOTS CLÉS

Ruminantia,

Andegameryx,

Procervulus,

micro-usure,

méso-usure,

paléoalimentation,

paléoécologie. than their relatives from others similarly aged localities in Europe. This fact raises an important evolutionary uncertainty concerning the traditional characterization of first pecorans as specialized browsers. Instead, data strongly corroborate the recently proposed notion that some Pecora ruminant lineages were able to consume a mixture of browse and grass, and that were originally facultative mixed feeders. However, there is a large degree of variation of their dental wear features. Species were not dependent on a limited type of vegetation and, consequently, were able to exploit different food resources. Dental wear data seem to indicate that these ruminants did not compete for vegetation. In addition, last Andegameryx and earliest Procervulus apparently had a sufficiently different body size to partition the available vegetation in terms of height above ground level to elude competition. Body size difference coupled with an important degree of dietary opportunism may have been factors necessary for their coexistence.

\section{RÉSUMÉ}

Comportement alimentaire et compétition pour les ressources végétales entre deux ruminants (Pecora, Artiodactyla) du Miocène inférieur d'Espagne.

Le comportement alimentaire et la compétition pour les ressources sont étudiés pour Andegameryx Ginsburg, 1971 et Procervulus Gaudry, 1877, deux petits ruminants représentatifs de deux stades successifs de diversification des Pecora. Les méthodologies de micro- et méso-usure dentaires ont été utilisées pour la reconstitution des préférences alimentaires. Les données obtenues pour les peuplements des bassins montagneux de la chaîne Ibérique (centre-est de l'Espagne) pendant le Miocène inférieur (MN3), indiquent que les deux ruminants peuvent être considérés comme mangeurs mixtes, quoiqu il y ait des différences entre les traits de leur usure dentaire. De plus, les taxons espagnols étudiés ont des régimes alimentaires moins abrasifs que leurs parents des autres localités du même âge en Europe. Ce fait remet en question l'hypothèse évolutive selon laquelle les premiers pécores auraient été des brouteurs sélectifs de plantes ligneuses (feuilles, bourgeons et fruits). En revanche, ces données appuient clairement l'idée proposée récemment selon laquelle quelques lignées de Pecora pouvaient originalement être mangeurs potentiels mixtes. Ils prélèveraient ainsi tous les types d'espèces végétales qu' ils auraient à leur disposition : la plus ou moins grande consommation de plantes ligneuses et de plantes herbacées dépendrait donc de leur disponibilité dans l'environnement où ils vivaient et non seulement de leurs préférences alimentaires. D'autre part, les derniers Andegameryx et les premiers Procervulus échapperaient à la concurrence grâce à leur différence de taille: puisque tous les deux mangeraient à des hauteurs différentes, leur régime alimentaire ne serait pas exactement le même. Ainsi, la différence de taille et un certain degré d'opportunisme alimentaire pourraient bien être des facteurs nécessaires à la coexistence de ces deux ruminants sur un même territoire.

\section{INTRODUCTION}

Effective partitioning of vegetal resources is a common phenomenon within extant herbivore communities and one of the most cited exampled is the separation of African ungulates (Gagnon \& Chew 2000). In a similar way as at present, extinct herbivore species are expected to be distributed such that they were able to balance and satisfy their requirements with the distribution and abundance of the vegetation (Gordon 2003). 
During the Early Miocene, the main faunal revolution in the herbivore community was the appearance and spread of the first horned ruminants. Cranial appendages were independently developed by several pecoran families in separated areas (MN3: 19-17 my). In Europe, first horned ruminants belonging to cervoid lineages appeared in the Ramblian localities, and coexisted with the hornless Pecora representatives of the Oligocene-Early Miocene radiation. The ruminants investigated in this study, Andegameryx Ginsburg, 1971 and Procervulus Gaudry, 1877, are representatives of these two largely distinct states of diversification of pecorans, and made up a notable component in the Early Miocene large mammal communities of Europe.

Andegameryx, one of the last representatives of the Oligocene-Early Miocene radiation of hornless Pecora, is well-known in the Early Miocene faunas of western and Central Europe (Ginsburg 1971, 1999; Ginsburg \& Morales 1989). In Spain, Andegameryx is first recorded in the Agenian locality of Cetina de Aragón (MN2) (Ginsburg et al. 1994) and is common in the Ramblian localities (MN3) from the Tagus and Calatayud basins (Quiralte \& Morales 2006). Although some authors placed it as possible Bovoidea (Morales et al. 1986; Gentry et al. 1999) or Cervoidea (Ginsburg et al. 1994; Ginsburg 1999), its origin is uncertain and the systematic position of Andegameryx is still under discussion. In turn, Procervulus is one of the oldest known pecorans bearing antler-like appendages. It is close to true cervids and has been considered either as the sister-group (Ginsburg 1985) or the most basal membership (Azanza 2000) of the family Cervidae. In Spain, Procervulus first appeared in the late Early Miocene (MN3), and became extinct during the Mid-Miocene general cooling (MN5).

Up to date, the association of the genera Andegameryx and Procervulus was only known in the late Early Miocene deposits of western and Central Europe, especially in France (MN3; Les Beilleaux, Les Buissonneaux-Pontigné, Noyant-sous-Le-Lude, Grand-Trouvé and Beaulieu [Ginsburg et al. 1985, 2000; Ginsburg 2001; Aguilar et al. 2003]) and Germany (MN3; Wintershof-West and MN4; Petersbuch 2 [Kaiser \& Rössner 2007]). Also, the co-occurrence of Andegameryx and Procervulus is documented in the Iberian Peninsula.
Despite the existence of numerous systematic studies focused on these two genera (Ginsburg 1985, 1999; Ginsburg \& Morales 1989; Azanza 1993, 2000; Rössner 1995), the knowledge on their paleoecology, and more specifically as far as dietary habits and competition are concerned, is still very poor. Recently, Kaiser \& Rössner (2007) furnished some important dietary information of both herbivores in a general analysis concerning the diversity of feeding niches in German Miocene ruminants and their resource partitioning. However, this study was only focused on the mesowear method. In addition, DeMiguel et al. (2008) proposed a facultative mixed-feeding state as the initial condition for deer by comparing microwear and mesowear results of Procervulus ginsburgi Azanza, 1993, from the Early Aragonian (MN4) of Spain. Interestingly, no detailed study focused on competition for vegetal resources between these two pecorans has been published to date to determine whether Andegameryx could have been ecologically replaced by Procervulus.

In this paper, we describe the feeding habits of latest Andegameryx and first Procervulus species recorded in the MN3 localities of Central Spain. Our study aimed to investigate the most effective mechanisms of partitioning the available vegetation for two brachydont herbivores. We also consider that new paleodietary data of these Early pecorans will contribute to evaluate the hypothesis which concerns the ancestral state of the Early Miocene ruminants. Because of the small size of Andegameryx and Procervulus, which would apparently result in an extensive height overlap in vegetation utilization, the most obvious way of partitioning the resources when they coexisted would be by displaying different feeding styles. If they showed no dietary differentiation, both herbivores should therefore have competed directly, especially when forage was of lower quality and less abundant (Hulbert \& Andersen 2001). As central and northeastern Spanish environments already became drier (Jiménez-Moreno et al. 2007a, b) while Early and Middle Miocene Central European habitats remained widely humid and densely forested (Fortelius et al. 2002), it is to be expected that lower quality vegetation was developed in the Spanish habitats. 


\section{MATERIAL AND METHODS}

\section{STUDY AREAS, COLLECTION OF SAMPLES} AND RUMINANT ASSOCIATED FAUNA

Our study was applied to the dentition of Andegameryx and Procervulus recorded in the Neogene basins of Calatayud and Rubielos de Mora. We selected the material of the three different localities described below by belonging to the intramountain basins of the Iberian Chain (Anadón et al. 2004), Central Spain, and therefore, to the same geological unity (Fig. 1).

The material representing the Calatayud basin was recovered from the localities of Ágreda and Moratilla, which are located on the sector of Calamocha (Daams et al. 1987; Anadón et al. 2004), while that representing the Rubielos de Mora basin comes from the locality of Alto de Ballester 1 (Montoya et al. 1996). These three localities are placed in the MN3 unit and local zone A of the Upper Ramblian on the basis of the rodent association (Daams et al. 1987; Montoya et al. 1996). Preliminary data on the ruminant assemblage of these fossil sites have been already published in several works (Morales $\&$ Soria 1984; Montoya et al. 1996; van der Made \& Morales 1999; Azanza 2000). Altogether the localities yielded several ruminant species, probably belonging to four different families. We found representatives of the first horned ruminants such as Paleomerycids of an intermediate size and first cervids represented by at least three different forms of small-sized Procervulus, co-occurring with the latest members of Andegameryx, and a form with similar morphology and size than the giraffoid Teruelia (although only represented in Moratilla).

In Agreda, the small size of Procervulus falls within the variability of the material of the type locality and, consequently, we maintain the assignation of Procervulus cf. praelucidus given by Rössner (1995). In contrast, the species represented in Moratilla has a bigger-sized $\mathrm{p} 2$ and shows differences in the morphology of the horns. These facts prevent us to classify it as Procervulus cf. praelucidus and, as suggested by Azanza (2000), we leave this material with open nomenclature as Procervulus sp. With respect to the species of Alto de Ballester 1, although it was classified as Procervulus dicho- tomus Ginsburg, 1990 by Montoya et al. (1996), its bigger size and different morphology display more resemblance to those of Procervulus ginsburgi. Therefore, it is here tentatively assigned as $P$. cf. ginsburgi. Nonetheless, a further systematic revision of the whole material of ruminants from these localities is the subject of a separate study which is currently in process.

Despite the fact that the ruminant fauna of these three localities is varied and extensive, only teeth of Andegameryx and Procervulus are known, and so both are the species investigated in the present work. Thus, we have analyzed a total of 26 dental remains. The specimens from Ágreda and Moratilla are housed in the Museo Nacional de Ciencias Naturales-CSIC (Madrid, Spain), whereas specimens from Alto de Ballester 1 are housed in the Museo Paleontológico de la Universidad de ZaragozaGobierno de Aragón (Zaragoza, Spain). For an easier understanding of the text, the abbreviations of the localities names (Ágreda [AGR], Moratilla [MOR] and Alto de Ballester 1 [AB1]) after " $A$." or " $P$." will be used as nomenclature, indicating a population of Andegameryx or Procervulus, respectively. Specimens of each locality correspond to a single species. Hence, analyses in this study have been realized only for specimen with a clear systematic affiliation on species level.

\section{BODY MASS ESTIMATION}

Mammalian body size is usually predicted by proximal limb bones (Scott 1983, 1990; Kholer 1993), cranial (MacFadden \& Hulbert 1990) or dental (Janis 1990) measurements. Because of the lack of appropriated postcranial and cranial remains among our material, we use single molars to estimate body size. The method applied in this study follows the procedure developed by Janis (1990) and M2 and/ or $\mathrm{m} 1$ length was measured.

We compared the body size of the Spanish species to that of both extant taxa and extinct populations coming from similarly aged European localities (Rössner 1995).

\section{DIETARY ASSSESSMENT}

Microwear and mesowear were used to infer the dietary behaviour of the studied taxa. These 
methodologies are proven to distinguish between browsing (fruit and leaf), mixed and grazing diets in a wide variety of living herbivorous mammals, and within lineages over geological time (Fortelius \& Solounias 2000; Solounias \& Semprebon 2002).

Dental microwear is the result of the abrasion of teeth by food items consumed during the last days prior to the death of the animal (Solounias \& Semprebon 2002). The method applied was performed following the previously procedure developed by Solounias \& Moelleken (1992). Microscopic features were observed using an Environmental Scanning Electron Microscope (ESEM), and directly categorized on the basis of the ratio length/width; scratches: 4 < ratio < 100; pits: ratio $=4$. Images were taken at a high magnification of $500 \times$ and were treated with specific software. The number of scratches and pits, which are variables commonly adopted for analysis, were transformed into a density score (Rivals \& Deniaux 2003) in order to simplify the comparison with other taxa. In addition to densities, we also introduce large pits, cross scratches and scratch texture (Solounias \& Semprebon 2002) as qualitative variables to further analyze fossil cases where microwear was controversial or unclear. The study focused, as far as possible, on the anterior lingual blade of the paracone on the M2 and the posterior buccal blade of the protoconid on the $\mathrm{m} 2$ permanent. Microwear variables of the extinct taxa were then compared to a database from 28 well-known extant taxa (Solounias et al. 2000) sharing the same protocol concerning high magnification $(500 \times)$ and SEM. The database was partitioned into the leaf $(\mathrm{N}=7)$ and fruit-browsing $(\mathrm{N}=3)$, grazing $(\mathrm{N}=7)$, seasonal $(\mathrm{N}=7)$ and non-seasonal $(\mathrm{N}=$ 4) mixed feeding categories.

The microwear signals of the species here analyzed were compared to those obtained in other Spanish Procervulus (DeMiguel et al. 2008, 2010). These are the only data available regarding dental microwear of Procervulus, while there is no microwear data for Andegameryx.

Dental mesowear is based on the physical properties of food as reflected in the relative amounts of attritive and abrasive wear that they cause on

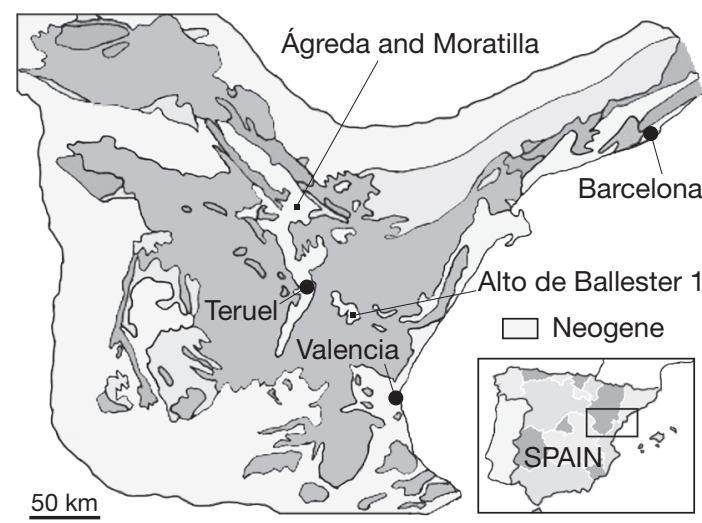

FIG. 1. - Location of the studied localities in the Iberian Chain (Central Spain). Ágreda and Moratilla are placed in the Calatayud basin, and Alto de Ballester 1 in the Rubielos de Mora basin.

the teeth (Fortelius \& Solounias 2000). Molar occlusal relief (high or low) and cusp shape (sharp, rounded, or blunt) of the apex of the paracone and metacone of the M1-M3 and the metaconid and entoconid of the m1-m3 were examined with the naked eye, or at low magnification of $4 x$ using a stereomicroscope when appropriate, and qualitatively scored. At this point, we would like to note that in order to gain a reasonably accurate classification of samples, we abandoned conventional practice introduced by Fortelius \& Solounias (2000) here in one point and included also lower teeth into the analyses for $A_{A G R}$ and $P_{A B 1}$. It was used all available molars except for those in very early and very late wear. This is due to the fact that cusp sharpness is sensitive to ontogenetic age among young individuals and among dentally senescent individuals, but is found to be less insensitive to age and more strongly related to diet when intermediate age individuals are used in the analyses (Rivals et al. 2007). A comparative extant database with known diets was followed as a reference (Fortelius \& Solounias 2000). Small samples represented by less than 10 individuals were removed in order to obtain a range in which distributions that look different become significantly different statistically. The dental mesowear of fossil species was compared to a set of 54 well-known extant ungulates composed of conservative leaf $(\mathrm{N}=9)$ 
TABLE 1. - Summary of body mass estimation, and microwear and mesowear patterns. Abbreviations: $\mathbf{L}$, length in mm; $\mathbf{N}$, number of individuals measured; $\mathbf{S}$, scratches per $\mathrm{mm}^{2}$; [SD], standard deviation; $\mathbf{P}$, pits per $\mathrm{mm}^{2} ; \% \mathbf{P}$, percentage of pits; \%H, percentage of individuals with high relief; $\% \mathbf{S}, \% \mathbf{R}, \% \mathbf{B}$, percentage of individuals with sharp (\%S), rounded (\%R) and blunt (\%B) cusps. Other abbreviations: see Material and methods.

\begin{tabular}{|c|c|c|c|c|c|c|c|c|c|c|c|c|}
\hline \multirow{2}{*}{$\begin{array}{l}\text { Localities } \\
\text { (Spain) }\end{array}$} & \multirow{2}{*}{ Species } & \multicolumn{2}{|c|}{ Body mass (Kg) } & \multicolumn{4}{|c|}{ Microwear } & \multicolumn{5}{|c|}{ Mesowear } \\
\hline & & M2 L. & m1 L. & $\mathbf{N}$ & $S$ [SD] & $P$ [SD] & $\% \mathrm{P}$ [SD] & $\mathbf{N}$ & $\% \mathrm{H}$ & $\% \mathrm{~S}$ & $\% R$ & $\% \mathrm{~B}$ \\
\hline AGR & Andegameryx & $32.05 \mathrm{~N}(1)$ & $31.71 \mathrm{~N}(4)$ & 4 & 531 [192] & 297 [81.3] & $37[4.5]$ & 8 & 87.5 & 57.1 & 42.9 & 0 \\
\hline AGR & Procervulus & $18.54 \mathrm{~N}(1)$ & - & 2 & $675[174]$ & $555[343]$ & $43[9.8]$ & 2 & 100 & 50 & 50 & 0 \\
\hline MOR & Procervulus & & & 3 & 645 [267.7] & 642 [26.3] & 51 [11] & 2 & 100 & 50 & 50 & 0 \\
\hline $\mathrm{AB} 1$ & Procervulus & & $28.40 \mathrm{~N}(2)$ & 4 & 839 [299.8] & 534 [183.9] & $40[6.1]$ & 13 & 92.3 & 14.3 & 85.7 & 0 \\
\hline
\end{tabular}

and fruit-browsing $(\mathrm{N}=8)$, conservative grazing $(\mathrm{N}=11)$ and conservative mixed feeder species $(\mathrm{N}=26)$. The duikers and hyraxes constitute part of the fruit-eaters as a special case (MABRA, for minute abraded brachydont) showing quite unclear dental wear. Note also that some cases are treated as mixed feeders in the conservative classification, and as browsers or grazers in the radical classification, and could be considered browse-dominated and grass-dominated mixed feeders, respectively.

We also compared our results with the mesowear data published for other Andegameryx and Procervulus from similarly aged German localities (Kaiser \& Rössner 2007). Thus, their relatives from Wintershof-West, Petersbuch 2 and Erkertshofen 2 were included and discussed in the analyses. As far as we know, these are the only data available regarding dental mesowear of Andegameryx and Procervulus in Europe.

Following DeMiguel et al. (2008), multivariate discriminant analyses were employed to categorize the most probable feeding style in fossils based on micro/mesowear data. In order to avoid possible taphonomic alterations, all specimens were carefully revised and those with extensive defects or badly preserved enamel surface and cusp shape were removed from the analyses. As a limiting factor in this study, we recognize the low number of dental specimens available in particular for the Procervulus from Ágreda and Moratilla. In order to fully assess the available information and compensate for the small sample size of these populations, we realized a variability study by using as a reference the results obtained from samples that are large enough.

\section{ABBREVIATIONS}

ESEM environmental scanning electron microscope; MABRA minute abraded brachydont;

SEM scanning electron microscope.

$\begin{array}{ll}\text { Locality } & \text { names } \\ \text { AGR } & \text { Ágreda; } \\ \text { MOR } & \text { Moratilla; } \\ \text { AB1 } & \text { Alto de Ballester } 1 .\end{array}$

\section{RESULTS}

The variables obtained in the analyses performed for the ruminant taxa from the localities of Ágreda, Moratilla and Alto de Ballester 1 are presented in Table 1.

\section{BODY MASS ESTIMATION}

According to the method described by Janis (1990), the body mass of $A_{A G R}$ was determined as approximately $32 \mathrm{~kg}$ (Table 1 ), comparable to extant Ammodorcas clarkei Thomas, $1891(31 / 25 \mathrm{~kg}$; Janis 1990). In the case of $P_{A G R}$ the body mass was around $18 \mathrm{~kg}$ (Table 1), and comparable to extant Elaphodus cephalopus Milne-Edwards, $1872(18 \mathrm{~kg}$; Janis 1990). The body mass of $P_{A B 1}$ was calculated on the basis of the $\mathrm{m} 1$ length as $28 \mathrm{~kg}$ (Table 1), and is similar to extant Muntiacus muntjak Zimmermann, 1780 (25 kg; Janis 1990).

Body mass of Andegameryx cf. laugnacensis from Wallernried (Switzerland) has been also predicted (Becker et al. 2001) by means of Janis (1990) and Legendre (1989) methodologies, being 16 and $32 \mathrm{~kg}$, respectively. It only differs from $A_{\mathrm{AGR}}$ when 

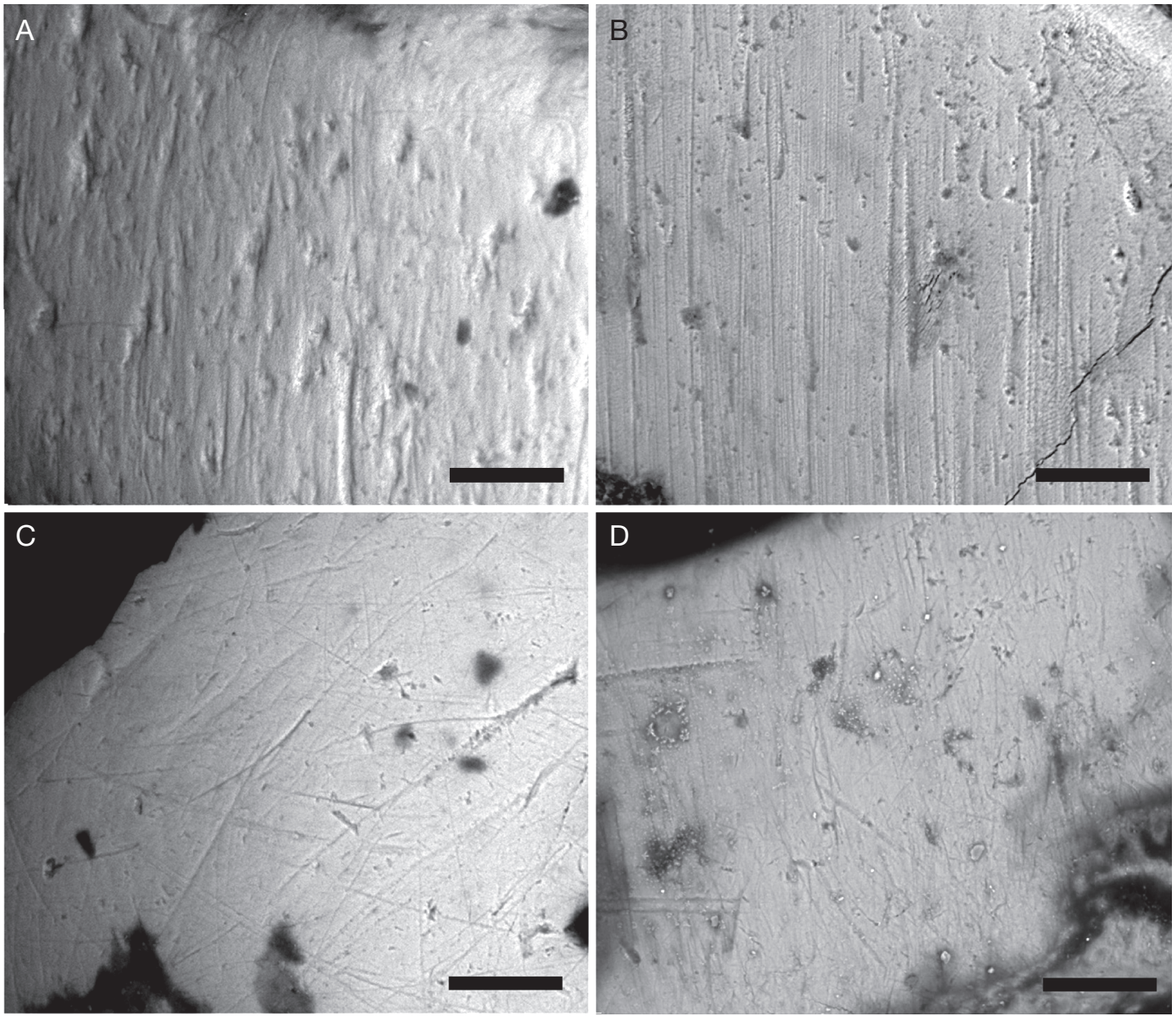

FIG. 2. - ESEM photomicrographs of share facets of the population of: $A, A_{A G R} ; B, P_{A G R} ; C, P_{M O R} ; \mathbf{D}, P_{A B 1}$. Scale bars: $100 \mu m$. Abbreviations: see Material and methods.

the first method is applied. Procervulus praelucidus Obergfell, 1957 from Wintershof-West (Eichstätt, Bavaria) is another primitive deer studied by Rössner (1995) and similar to that of $\mathrm{P}_{\mathrm{AGR}}$. We estimated its mass as approximately $14 \mathrm{~kg}$ (M2 length) or $22 \mathrm{~kg}$ (m1 length).

Therefore, comparisons between our taxa and other existing species of Andegameryx and Procervulus result in a clear mass similarity.

\section{MICROWEAR}

Microwear analysis reveals the presence of significant differences on the occlusal surfaces of fossil species.
Three different patterns can be observed among the sample; one showing low scratching and pitting $\left(A_{A G R}\right.$; Table 1; Fig. 2A), one exhibiting a pattern comprised of low scratching but an intermediate pitting $\left(\mathrm{P}_{\mathrm{AGR}}\right.$ and $\mathrm{P}_{\mathrm{MOR}}$; Table 1; Fig. $\left.2 \mathrm{~B}, \mathrm{C}\right)$, and one displaying a moderately high scratching and an intermediate pitting $\left(\mathrm{P}_{\mathrm{AB} 1}\right.$; Table 1; Fig. 2D).

\section{Comparison with living species}

When compared to extant ungulates, microwear of $\mathrm{P}_{\mathrm{AGR}}, \mathrm{P}_{\mathrm{MOR}}$ and $\mathrm{A}_{\mathrm{AGR}}$ clearly shares strong affinities with fruit-eaters such as Cephalophus dorsalis Gray, 1849 (Fig. 3). In contrast, living 
leaf-browsers (Litocranius walleri Brooke, 1878 or Alces alces Linnaeus, 1758) have a density of pits that is significantly higher than that of the fossils of this study (Fig. 3). It is apparent from examining the density of scratches and pits that $\mathrm{P}_{\mathrm{AB} 1}$ most closely resembles to mixed feeders with a seasonal preference for graze, such as Taurotragus oryx Pallas, 1766 (Fig. 3). Clear differences are evident in the microwear when comparing with grazers, since the density of scratches is much higher for this extant group (Fig. 3).

\section{Comparison with fossil species}

As far as we know, the only data available regarding dental microwear of fossil Procervulus have been reported in DeMiguel et al. (2008, 2010), whereas there is no microwear data for Andegameryx.

The difference in term of density of scratches is evident between the species of this study and those from other Spanish localities, since their teeth display lower values (Fig. 3), and only Procervulus from San Marco (MN4, biozone B) exhibits a similar scratching. This indicates that the cervids from Ágreda, Moratilla and Alto de Ballester 1 might have been less involved in grazing. As a whole, the species analyzed in this study differ from the others by having slightly higher densities of pits (Fig. 3). Procervulus ginsburgi seems to be more inclined toward the grass-dominated end of the mixed feeder continuum than $\mathrm{P}_{\mathrm{AB} 1}$, as suggest its higher scratching (Fig. 3).

\section{Dietary assignment based on dental microwear}

In order to force the classification of Andegameryx and Procervulus cases into an established feeding category, a discriminant analysis was realized. A very high discrimination of $82.1 \%$ was given among the 28 extant taxa (Fig. 4A2). It must be noted that no extant browsers were misclassified as grazers or vice versa. By displaying browser affinities, the microwear classifies $\mathrm{A}_{\mathrm{AGR}}$ into the fruit-browser category (Fig. 4A1). The results show that all specimens with the exception of one (a leaf-browser) were classified as frugivorous (Fig. 4A2). Although most of the Procervulus populations were also classified as fruit-browsers (Fig. 4A1), it was found a significant dietary het- erogeneity among their specimens, having fruit and leaf-browsing, mixed, and even grazing habits (Fig. 4A2). $\mathrm{P}_{\mathrm{AGR}}$ and $\mathrm{P}_{\mathrm{MOR}}$ were classified as frugivorous, and it seems that an important volume of fruits and seeds was taken by them just before death. $\mathrm{P}_{\mathrm{AB} 1}$ was however placed in the category of seasonal mixed feeders (Fig. 4A1). Some of its specimens were classified as seasonal mixed feeders, and some others as grazers and leaf-browsers (Fig. 4A2), which is commonly considered as a seasonality signal (Solounias \& Moelleken 1994; Merceron et al. 2004).

In order to better understand diets for limited samples, we used an analysis (Fig. 7) based on the dispersion of all studied specimens according to the morphospace of variability that was obtained from the microwear of Procervulus cf. ginsburgi from Alto de Ballester 1 (this study) and Procervulus ginsburgi from Artesilla (DeMiguel et al. 2008). The reason for using these samples, classified as seasonal mixed feeders based on both micro-and mesowear, is that they are large enough to recognize specimens within the smallest populations that could be shifted toward the browse-dominated or the grass-dominated end of the mixed feeder continuum.

Most of the cases belonging to $\mathrm{P}_{\mathrm{AB} 1}$ plotted inside the area represented by the variability continuum of Artesilla (three specimens of four), thus indicating that this cervid most likely had a seasonal mixed feeder strategy. Their emplacements also show that this species was less inclined to grazing that Procervulus ginsburgi. Similarly, specimens from $\mathrm{P}_{\mathrm{AGR}}$ plotted inside the variability continuums. This result does not support the hypothesis that exclusive browsing was exhibited by $\mathrm{P}_{\mathrm{AGR}}$, and gives a convincing evidence that Procervulus cf. praelucidus and German Procervulus praelucidus were significantly different in nutrient exploitation. When specimens from $\mathrm{P}_{\mathrm{MOR}}$ and $\mathrm{A}_{\mathrm{AGR}}$ are observed, we note that their emplacements outside the continuums are due to exhibit lower densities of scratches than others; a signal characteristic of leaf-browsers, as demonstrated by the discriminant analysis. Therefore, these emplacements seem to be coherent with both the fact of being browser populations, or specimens 


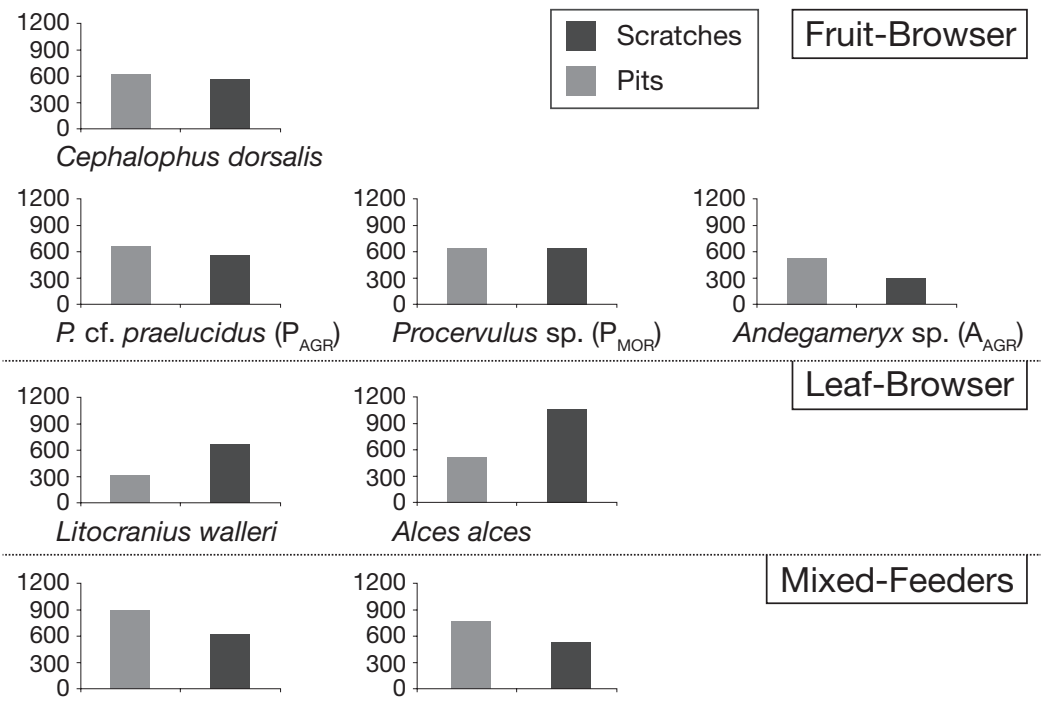

Taurotragus oryx Gazella granti

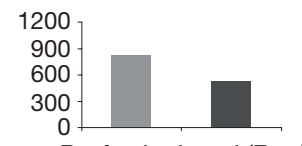

P. cf. ginsburgi $\left(\mathrm{P}_{\mathrm{AB} 1}\right)$

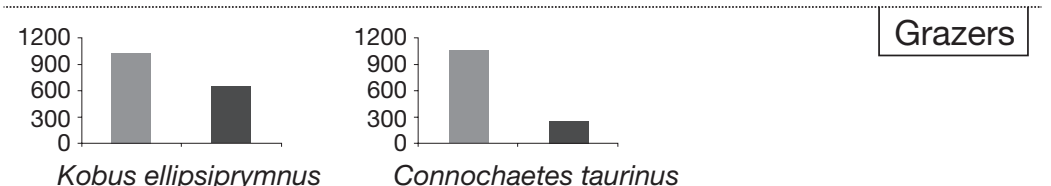

Kobus ellipsiprymns Connochaetes taurinus

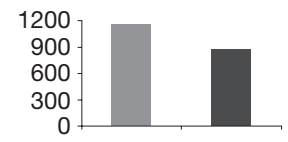

Procervulus ginsburgi

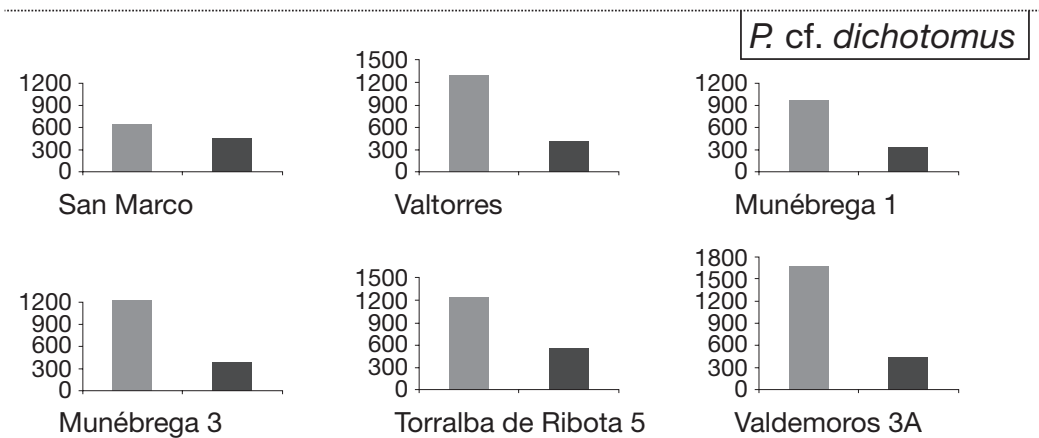

FIG. 3. - Histogram showing the density of scratches and pits for the Spanish taxa with living species and with Procervulus from other Spanish localities. Dental microwear data of living taxa and Procervulus taken from Solounias et al. (2000) and DeMiguel (2008, 2010), respectively. Abbreviations: see Material and methods. 

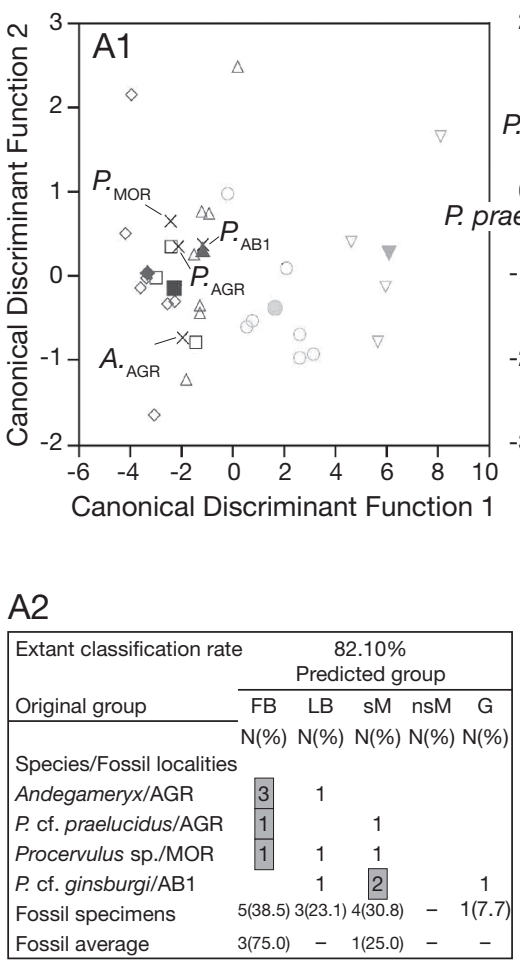

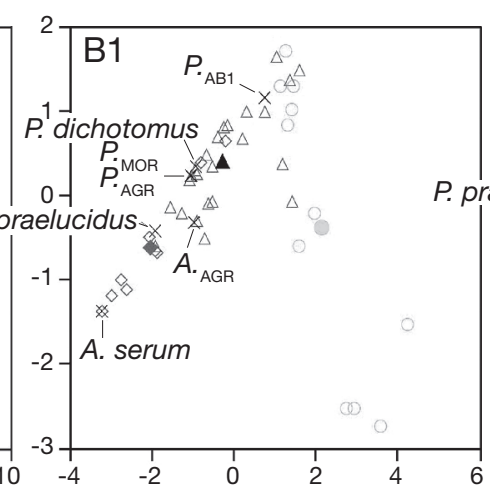

B2

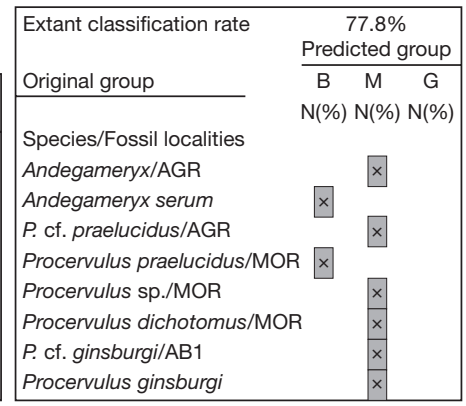

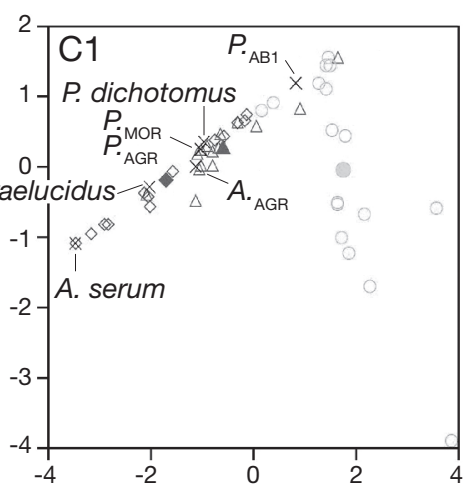

C2

\begin{tabular}{|c|c|c|c|}
\hline \multirow{2}{*}{$\begin{array}{l}\text { Extant classification rate } \\
\text { Original group }\end{array}$} & \multicolumn{3}{|c|}{$\begin{array}{l}75.6 \% \\
\text { Predicted group }\end{array}$} \\
\hline & $B$ & $\mathrm{M}$ & $\mathrm{G}$ \\
\hline & $\mathrm{N}(\%)$ & $\mathrm{N}(\%)$ & $\mathrm{N}(\%)$ \\
\hline Species/Fossil localities & & & \\
\hline Andegameryx/AGR & & $x$ & \\
\hline Andegameryx serum & $x$ & & \\
\hline P. cf. praelucidus/AGR & & $x$ & \\
\hline Procervulus praelucidus/MOR & & & \\
\hline Procervulus sp./MOR & & $x$ & \\
\hline Procervulus dichotomus/MOR & & $x$ & \\
\hline P. cf. ginsburgi/AB1 & & & $x$ \\
\hline Procervulus ginsburgi & & & $x$ \\
\hline
\end{tabular}

FIG. - 4. Distribution of species in the morphospace defined by the discriminant analyses: $\mathbf{A}$, microwear analysis developed using as criterion variables density of scars; B, C, mesowear without MABRA based on the percentage of round and blunt cusps, and high occlusal relief using the conservative classification (B) and the radical classification (C). Closed symbols representing centroids. Dental mesowear data of $A$. serum Obergfell, 1957, $P$. praelucidus Obergfell, 1957 and $P$. dichotomus Ginsburg, 1990 given by Kaiser \& Rössner (2007). Abbreviations: B, browser; FB, fruit-browser; G, grazer; LB, leaf-browser; M, mixed feeder; nsM, nonseasonal mixed-feeder; sM, seasonal mixed-feeder.

forming part of the leaf-browser end of a mixed feeder population.

\section{MESOWEAR}

Teeth of $\mathrm{A}_{\mathrm{AGR}}, \mathrm{P}_{\mathrm{AGR}}$ and $\mathrm{P}_{\mathrm{MOR}}$ display mesowear comprised of a predominance of high occlusal relief, a combination of similar percentages of sharp and rounded cusps, and no incidence of blunt cusps (Table 1). In some populations, this last fact could be due to the scarce sample, but may also suggest that diets were not highly abrasive. When looking separately at the percentages of sharp and rounded cusps, it is noted that in $\mathrm{A}_{\mathrm{AGR}}$ (Fig. 5A, B) the proportions of sharp cusps are higher (having less rounded apices) than those of $\mathrm{P}_{\mathrm{AGR}}$ (Fig. 5C, D) and $\mathrm{P}_{\mathrm{MOR}}$ (Fig. 5E, F), probably because of a lower abrasiveness of the preferred food items. Ma- jor differences are however found in the mesowear pattern of $\mathrm{P}_{\mathrm{AB} 1}$ (Table 1; Fig. 5G, H). The molar teeth of this extinct cervid are characterized by a predominance of high relief and rounded cusps, though also display significant proportions of sharp cusps. This is a highly abrasion-dominated mesowear pattern, and clearly differs from those of the other fossils investigated.

\section{Comparison with living species}

When compared to living ungulates of the three dietary categories (Fig. 6), fossil species have a pattern similar to those of the "traditional" mixed feeders, which usually have about 50\% sharp and 50\% rounded cusps, and no incidence of blunt cusps (Fortelius \& Solounias 2000). In detail, $A_{A G R}$ displays a very similar pattern to Ovibos moschatus Zimmermann, 1780 (Fig. 6), and 
to a lesser extent to Gazella thomsoni Günther, 1884. The mesowear pattern of $\mathrm{P}_{\mathrm{AGR}}$ and $\mathrm{P}_{\mathrm{MOR}}$ is exactly the same as that of Tragelaphus scriptus Pallas, 1766 and Taurotragus oryx (Fig. 6), whereas results for $\mathrm{P}_{\mathrm{AB} 1}$ are very close to that observed for extant Ourebia ourebi Zimmermann, 1783 (Fig. 6), suggesting a higher degree of abrasion than the "traditional" mixed feeders, as was obtained in microwear. Indeed, this African bovid exhibits a highly abrasion-dominated wear, and is either treated as a mixed feeder in the conservative and as a grazer in the radical dietary classification.

None of the fossil species show similar patterns of mesowear to living grazers (Fig. 6). In general, typical grazers have significantly lower relief and higher percentages of rounded and blunt cusps. Data from Fortelius \& Solounias (2000) show these differences even in species represented by few specimens (Damaliscus lunatus Burchell, 1823; $\mathrm{N}=5$ ). When compared to living browsers, Dendrohyrax dorsalis Fraser, 1855 has the most similar mesowear signature with $82 \%$ high relief and approximately 50\% sharp and 50\% rounded cusps (Fortelius \& Solounias 2000).

\section{Comparison with fossil species}

The mesowear signatures of the Spanish populations can be compared with those obtained by Kaiser and Rössner (2007) for Andegameryx and Procervulus from Wintershof-West, Petersbuch 2, and Erkertshofen 2. Molar teeth of Andegameryx serum Obergfell, 1957 (100\% high, 100\% sharp) and Procervulus praelucidus Obergfell, 1957 (100\% high, 70\% sharp, 30\% rounded) display a mesowear mostly comprised of high occlusal relief and sharp cusps. Conversely, Procervulus dichotomus (100\% high, 47\% sharp, $53 \%$ rounded) displays a pattern characterized by a combination of sharp and round cusps and by a predominance of high occlusal relief. According to Kaiser \& Rössner (2007), both Andegameryx serum and Procervulus praelucidus share affinities with extant browsers (Alces alces and Giraffa camelopardalis Linnaeus, 1758) whereas Procervulus dichotomus shows a more abrasive signature close to that of Tragelaphus scriptus and Taurotragus oryx mixed feeders.

The percentage of occlusal relief and cusp shape for the Spanish and German species is shown in Figure 6. Neither species shows any incidence of blunt cusps, reflecting that the diets did not include any highly

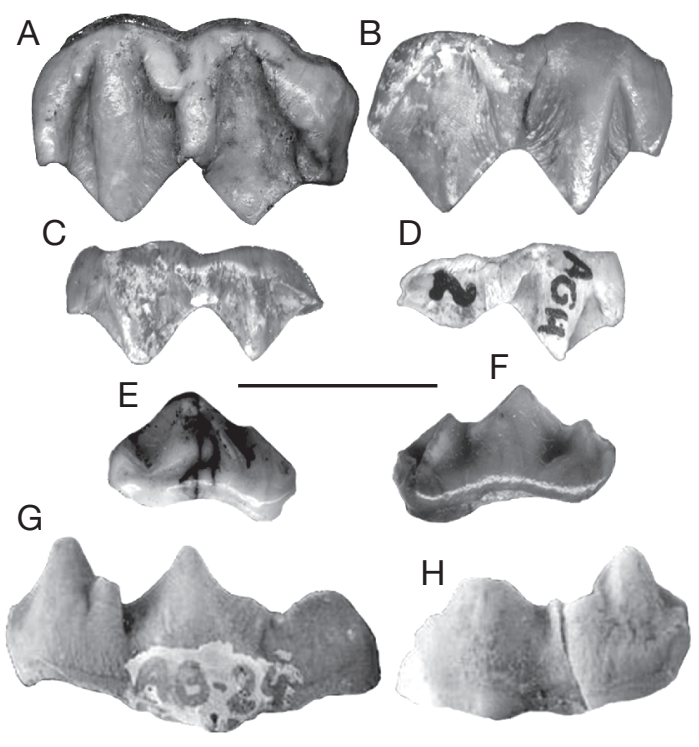

FIG. 5. - Mesowear features of selected teeth of: A, B, $A_{A G R}$; C, D, $\mathrm{P}_{\mathrm{AGR}}$; E, F, $\mathrm{P}_{\mathrm{MOR}} ; \mathbf{G}, \mathbf{H}, \mathrm{P}_{\mathrm{AB} 1}$. Scale bar: $1 \mathrm{~cm}$. Abbreviations: see Material and methods.

abrasive material such as phytoliths rich grasses. The high occlusal relief also suggests that, in general, the diets were not very abrasive. There is no significant difference between Procervulus dichotomus and both $\mathrm{P}_{\mathrm{AGR}}$ and $\mathrm{P}_{\mathrm{MOR}}$ (Fig. 6). This fact indicates that they had diets consisting of very similar properties, although the sample sizes of these latter species are not adequate to provide conclusive results. There is, however, a considerable variation in the percentages of rounded and sharp cusps between the German Andegameryx serum and Procervulus praelucidus and the Spanish $\mathrm{A}_{\mathrm{AGR}}$ and $\mathrm{P}_{\mathrm{AB} 1}$ (Fig. 6). In these cases, sample size is appropriate and is enough to offer well-supported results. Thus, it is noteworthy the $42.9 \%$ vs $0 \%$ rounded between Spanish and German Andegameryx, respectively. Such significant difference cannot be attributed to the sample size ( $\mathrm{N}=8$ and 25 specimens, respectively). In addition, higher percentages of sharp cusps are exhibited by the German populations (Fig. 6).

According to these results, the differences in mesowear are at least suggestive that the Spanish $A_{A G R}$ and $\mathrm{P}_{\mathrm{AB} 1}$ had diets consisting of more abrasive material, and were closer to being mixed feeders. 
Mesowear in $\mathrm{P}_{\mathrm{AB} 1}$ are very close to that observed for Procervulus ginsburgi, although the cervid from Alto de Ballester 1 shows a less abrasion dominated signal.

\section{Dietary assignment based on dental mesowear}

A first mesowear discriminant analysis was performed using the full dataset of 54 extant taxa, but the mean percentage correctly classified was only $61.1 \%$. $A_{A G R}$, $\mathrm{P}_{\mathrm{AGR}}$ and $\mathrm{P}_{\mathrm{MOR}}$ were here classified as mixed feeders, while $\mathrm{P}_{\mathrm{AB} 1}$ was a fruit-browser. This discrimination is not statistically significant to be sure of the dietary assignments and could be therefore partially or completely masked by the species involved in frugivory (MABRA group). Taxa that are well known to be highly frugivorous have a significant abrasion-dominated mesowear signal, probably because of tip-crushing wear due to frugivory. Thus, both extant and extinct species displaying mixed dietary strategies can be misclassified as frugivorous (Fortelius \& Solounias 2000). For this reason, $P_{A B 1}$ could be one of the several mixed feeder species misclassified, and in our opinion, it should be better to make the analysis by excluding the MABRA group.

When it was weeded out of the data, the percentage of correctly classified notably increased for both the conservative (77.8\%; Fig. 4B2) and radical (75.6\%; Fig. 4C2) classifications. Then, the most probable dietary assignment for $\mathrm{A}_{\mathrm{AGR}}, \mathrm{P}_{\mathrm{AGR}}$ and $\mathrm{P}_{\text {MOR }}$ corresponds to a mixed feeder according to both the conservative and radical classifications, whereas $\mathrm{P}_{\mathrm{AB} 1}$ was either a mixed feeder according to the conservative or a grazer according to the radical.

When the German Andegameryx and Procervulus (Kaiser \& Rössner 2007) are included in the discriminant analyses, both $A$. serum and $P$. praelucidus fit into the range of browsers (Fig. 4B2, $\mathrm{C} 2$ ), corroborating that ligneous food was a major component of their diets. The comparison with the Spanish relatives $\left(\mathrm{A}_{\mathrm{AGR}}, \mathrm{P}_{\mathrm{AGR}}, \mathrm{P}_{\mathrm{MOR}}\right.$ and $\left.\mathrm{P}_{\mathrm{AB} 1}\right)$ reveals that $A$. serum and also, but to a lesser extent, $P$. praelucidus, had a less abrasive diet (Fig. 4B1, C1). We also find that $P$. dichotomus was placed in the category of mixed feeders (Fig. 4B2, C2), and it seems clear that consumed abrasives on a more frequent basis than $\mathrm{A}_{\mathrm{AGR}}, \mathrm{P}_{\mathrm{AGR}}$ and $\mathrm{P}_{\mathrm{MOR}}$, while seems to have enjoyed a less abrasive type of diet than $\mathrm{P}_{\mathrm{AB} 1}$ (Fig. 4B1, C1).

\section{DISCUSSION}

As mentioned before, the faunal assemblage of the Ramblian localities from the central part of Spain is composed by at least four different ruminant taxa having brachydont dentitions. Andegameryx and Procervulus probably did not compete directly with Paleomeryx Lartet, 1851 and Teruelia Moyà-Solà, 1987, the other Pecora ruminants. Species could have occupied the same habitat, but the much larger body size of this cervoid and giraffid probably allowed them to avoid competition with the smallest ruminants.

Body mass of $\mathrm{P}_{\mathrm{AB} 1}$ was determined as approximately $28 \mathrm{~kg}$. Particular attention is given to the two fossil species which occurred in Ágreda. Thus, body mass calculated for $A_{A G R}(32 \mathrm{~kg})$ and $P_{A G R}(18 \mathrm{~kg})$ differs by about $50 \%$. Because extant ruminants of similar size usually avoid competition by living and feeding in different habitats (Dinerstein 1987), it might be expected that two species as different in size as $\mathrm{A}_{\mathrm{AGR}}$ and $\mathrm{P}_{\mathrm{AGR}}$ partitioned the available vegetation in terms of height above ground level (Hulbert \& Andersen 2001). Consequently, body mass difference could have been a factor preventing competition.

Hutchinson (1959) noted that ecologically similar species of mammals differed in mass by at least a factor of about 2.0-2.2. He interpreted this ratio as the minimum amount of similarity sufficient to decrease competition for limiting resources between individuals of sympatric species to a degree where coexistence was possible (Hutchinson 1959; MacFadden \& Hulbert 1990). $A_{A G R}$ and $P_{A G R}$ have a ratio of body mass very close to 1.8 . Given this value, and following the results of Hutchinson (1959), Andegameryx and Procervulus should be interpreted as non sympatric species and, therefore, should not have coexisted in Ágreda. Although Hutchinson's mass ratios have figured importantly in paleoecology, it must be noted that several authors have indicated that these ratios are not necessarily the product of competition (Eadie et al. 1987), and must be therefore used with caution, or even not be applied to fossil faunas (Van Valkenburgh 1990). Additionally, the coincidence of Andegameryx and Procervulus not only in the Spanish deposits here 

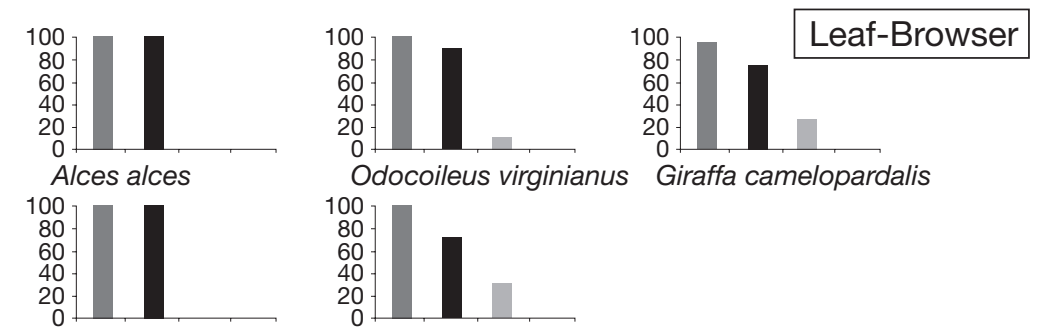

Giraffa camelopardalis
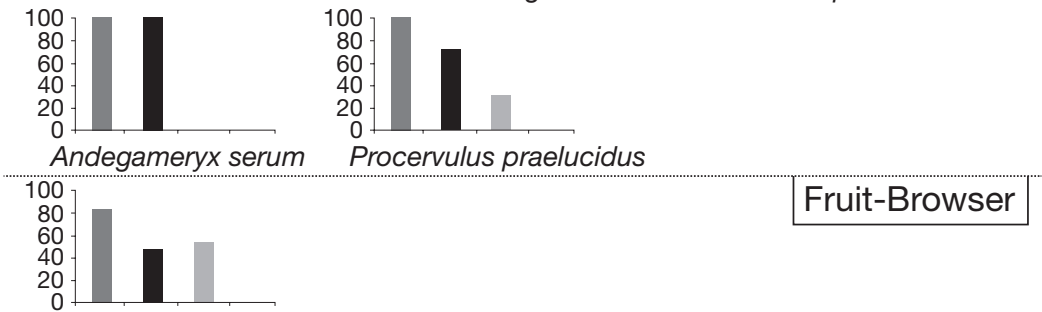

\section{Cephalophus dorsalis}
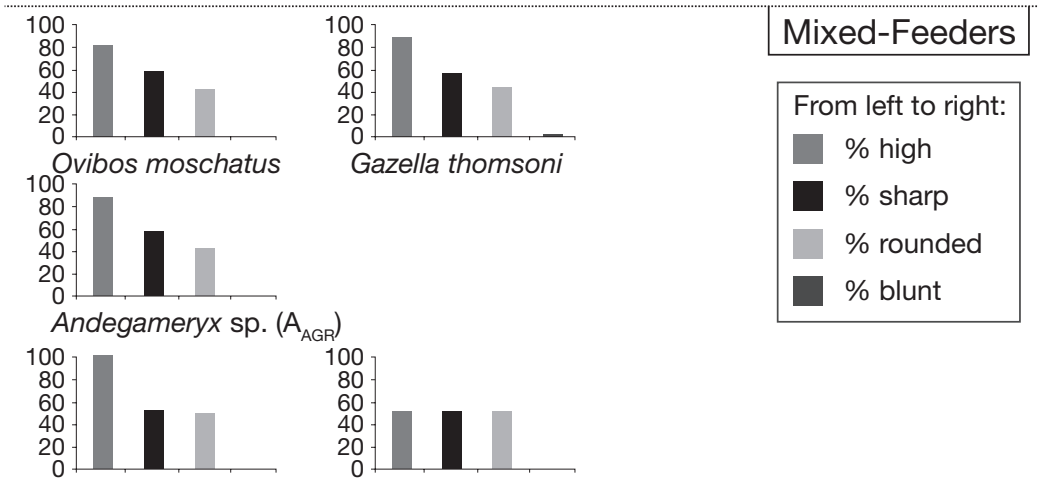

Tragelaphus scriptus
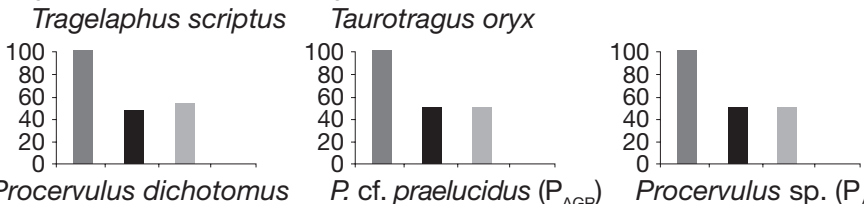

\section{Procervulus dichotomus}

P. cf. praelucidus $\left(\mathrm{P}_{\mathrm{AGR}}\right)$

Procervulus sp. $\left(\mathrm{P}_{\mathrm{AGR}}\right)$

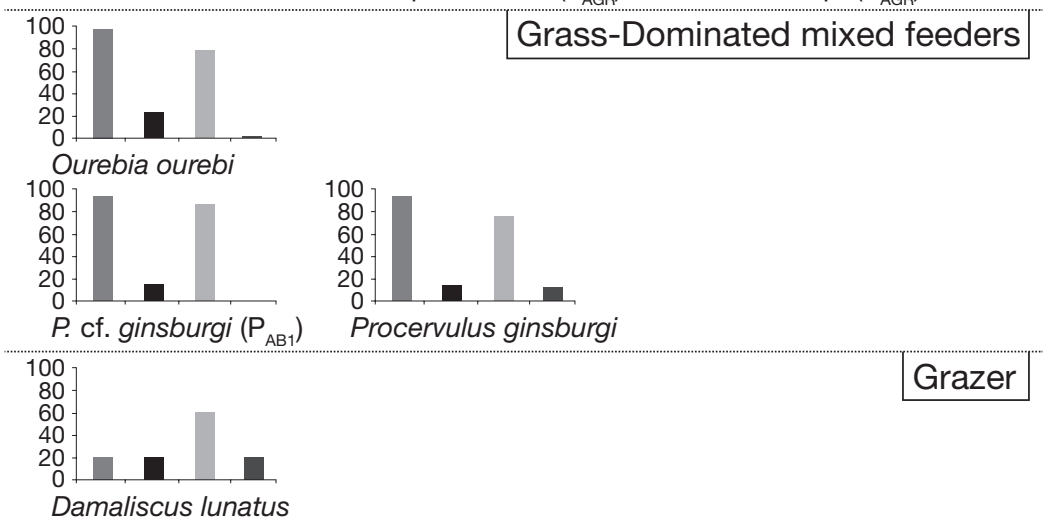

FIG. 6. - Histograms showing the percentage of high and low occlusal relief and of each type of cusp shape for the Spanish taxa with living species and with fossil populations of Andegameryx Ginsburg, 1971 and Procervulus Gaudry, 1877 from Europe. Dental mesowear data of living taxa taken from Fortelius \& Solounias (2000). Data of German taxa and fossil Procervulus ginsburgi Azanza, 1993 taken from Kaiser \& Rössner (2007) and DeMiguel et al. (2008), respectively. Abbreviations: see Material and methods. 
investigated, but also in other from France and Germany, is a strong argument in support of the hypothesis that both genera coexisted.

They, therefore, are expected to display any difference to have been co-occurring in the same environment.

Microwear studies placed $\mathrm{A}_{\mathrm{AGR}}, \mathrm{P}_{\mathrm{AGR}}$ and $\mathrm{P}_{\mathrm{MOR}}$ within the class of fruit-browsers, while suggested that $\mathrm{P}_{\mathrm{AB} 1}$ more closely resembles seasonal mixed feeders.

Densities are similar in both $\mathrm{P}_{\mathrm{AGR}}$ and $\mathrm{P}_{\mathrm{MOR}}$, but there is a pronounced difference in $A_{A G R}$ since this species has a much lower proportion of pits, and also, but to a lesser extent, of scratches. In addition, and despite the fact that some of the samples studied are not particularly rich, there are mixed feeder specimens within $\mathrm{P}_{\mathrm{AGR}}$ and $\mathrm{P}_{\mathrm{MOR}}$, whereas absence in $A_{A G R}$ (as can be seen in Fig. 4A2). All these facts reveal the presence of remarkable differences in the way to exploit the nutrients. The pattern of $A_{A G R}$ indicates a decrease in abrasion which can be related to a lesser proportion of grass in its diet (Solounias \& Semprebon 2002; Valli \& Palombo 2008). Moreover, and because frugivory is displayed in most of the $\mathrm{A}_{\mathrm{AGR}}$ specimens (75\%), it probably fed on fruits and seeds with softer coverings, compared to the other ruminants living in Âgreda and Moratilla. Regarding the species co-occurring in Ágreda, this fact could be either explained if: 1) Andegameryx was feeding on different type of fruits and seeds than Procervulus; or 2) Andegameryx incorporated these nutrients directly from the plant, while Procervulus ingested a greater proportion of grit and dust by eating the fallen items (Williams \& Kay 2001; Mainland 2003). Any of these two possible explanations could be considered as a mechanism preventing competition, but since the smaller body size of Procervulus likely allowed it to feed on closer the ground, the latter interpretation seems more tenable.

The microwear pattern of $\mathrm{P}_{\mathrm{AB} 1}$ significantly differs from the other ruminants investigated in having a much higher density of scratches.

Intensive scratching has been traditionally considered as the product of abrasive of silica phytoliths, and consequently of grazing (Solounias \& Moelleken 1992; Solounias et al. 2000; Merceron et al. 2005). However, a recent study proposed that silica phytoliths are softer than dental enamel and that a high scratch density should be rather regarded as the result of exogenous grit and deposited dust (Sanson et al. 2007). Despite the fact that this hypothesis requires verification, it is clear that exogenous particles certainly have a significant influence on the dental microwear (Solounias \& Semprebon 2002; Mainland 2003; Merceron et al. 2007; DeMiguel et al. 2008). Nonetheless, the results of the present study are not influenced by the debate on the causes behind a significant abundance of scratches because all the hypotheses correlate, in larger or lesser extent, an intensive scratching to the amount of consumed graminoids (see Merceron et al. 2007 for a review).

According to this, $\mathrm{P}_{\mathrm{AB} 1}$ apparently depended on more grasses than the other fossil taxa. Its abundance of scratches is not high enough to be a grazer, and its microwear might therefore be interpreted to represent a seasonal mixed feeding diet with a component of grass and browse to explain the moderately high scratching and the intermediate pitting. The higher scratching in some specimens is probably justifiable as a consequence of the consumption of fresh grasses in a wet season, while the higher pitting of others suggests a likely intake of browse (fruits, hard seeds) during a dry season. This seasonal dietary signal is in full agreement with the plant macroremains of ecosystems that were developed around Alto de Ballester 1. Thus, it could be due to changes in vegetation, coherent with a cyclicity likely related to the effects of periodic level oscillations of the Rubielos de Mora Lake, and controlled by climatic changes (Jiménez-Moreno et al. 2007b).

Regarding the mesowear, all the ruminant species probably had a mixed feeding behaviour, and therefore they consumed a mixture of both grass and browse.

Although only this major dietary trait is represented in the localities, mesowear seems to point out some considerable differences in the feeding habits of the species. There is no variation in occlusal height relief and cusp morphology among $\mathrm{P}_{\mathrm{AGR}}$ and $\mathrm{P}_{\mathrm{MOR}}$, and consequently no differences in their feeding adaptations, but some variations are however suggested to $A_{A G R}$, as seen in microwear. The lower percentages 
of rounded cusps indicate that a smaller proportion of abrasives was consumed (Fortelius \& Solounias 2000), suggesting therefore that grasses were not a major component of its diet. Mesowear also shows that $\mathrm{P}_{\mathrm{AB} 1}$ had $87.5 \%$ rounded cusps, and consequently a more important degree of dental abrasion, which is probably justifiable as a consequence of a significant consumption of grasses.

If interpreted independently, microwear signals depict $A_{A G R}, P_{A G R}$ and $P_{M O R}$ as fruit-browsers and $\mathrm{P}_{\mathrm{AB} 1}$ as a seasonal mixed feeder, while mesowear classifies these species as mixed feeders. The apparent inconsistency in temporal resolution between the short-term and long-term dietary signals may be a consequence of seasonal dietary fluctuation, that is, mixed feeding preferences (Solounias \& Moelleken 1992; Merceron et al. 2005; Valli \& Palombo 2008). Alternatively, this discrepancy could also be related to a truncated mesowear signal that occurs in species highly involved in frugivory (Merceron et al. 2007; Schulz et al. 2007). Despite the fact that low number of specimens for $\mathrm{A}_{\mathrm{AGR}}, \mathrm{P}_{\mathrm{AGR}}$ and $\mathrm{P}_{\mathrm{MOR}}$ prevents us from certainty concluding whether they were mixed feeders or fruit-browsers, the above study of variability (see results section) seems to rule out an exclusive frugivory as feeding type. In addition, when the enamel surface of $\mathrm{P}_{\mathrm{AGR}}$ is further studied, it is observed that it has not numerous large pits, and that scratches are generally uniform in size and depth, whereas that of $\mathrm{P}_{\mathrm{MOR}}$ is distinguished by having mainly numerous fine scratches (few coarsely textured scratches are present), small percentages of large pits and high percentages of cross scratches. These features suggest significant differences with extant fruitbrowsers (Solounias \& Semprebon 2002; Rivals et al. 2007). The first interpretation seems therefore more tenable to explain the inconsistency between micro- and mesowear.

Taken together, the evidences from dental microand mesowear argue for mixed feeding diets for all the pecoran species analyzed, with a significant proportion of frugivory for $\mathrm{A}_{\mathrm{AGR}}, \mathrm{P}_{\mathrm{AGR}}$ and $\mathrm{P}_{\mathrm{MOR}}$, and of grazing for $\mathrm{P}_{\mathrm{AB} 1}$.

Results therefore indicate the two species cooccurring in Ágreda had the same dietary regime. However, the considerable degree of variation of

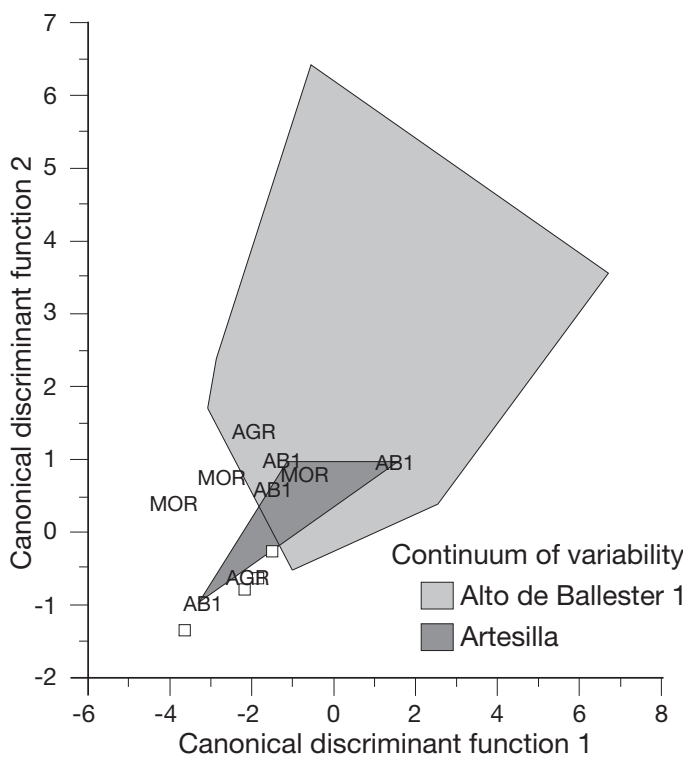

FIG. 7. - Variability morphospace of the large samples (Alto de Ballester 1, this study and Artesilla; DeMiguel et al. 2008) and distribution of specimens belonging to the small samples. Squares representing specimens of Andegameryx Ginsburg, 1971 and letters specimens of Procervulus Gaudry, 1877. Abbreviations: see Material and methods.

their dental wear features may be explained by the fact that they had different foraging behaviour and consequently exploited different food resources. As a result, Andegameryx ate a greater proportion of low-abrasion fruits and seeds and a lesser proportion of grasses than Procervulus.

Compared to the similarly aged German localities, no browsing and more mixed feeding Andegameryx and Procervulus are found in the Ramblian localities of Spain. The higher proportion of typical browsing mesowear signatures accounts for less abrasive regimes in Germany, which is interpreted as an indication of humid and forested habitats (Kaiser \& Rössner 2007). In Spain, however, more abrasive regimes are found among Andegameryx and Procervulus, and the overall climate seems to have been drier, which is in accordance with the pollen and macroflora available data (Jiménez-Moreno et al. $2007 \mathrm{a}, \mathrm{b})$. Thus, if aridity restricted the vegetal resources, Spanish pecorans could have been forced to display mixed feeder strategies to extract nutrients from a wide variety of vegetation. 
With respect to other dietary data from the Early Miocene, Eronen et al. (2010) also observed that ungulates exhibited more abrasive diets in Spain in this epoch, compared to those of Germany. This fact, in combination with our results, is well in accordance with the notion that Spain was the first region experiencing increasingly arid conditions in the Early Miocene of Europe (Van Dam 2006; Eronen et al. 2010).

Some other fossil taxa belonging to the same species are known to have reflected different feeding regimes when they were present in different habitats. Lagomeryx pumilio Roger, 1896 is a good example of a species inclined to browsing in a wetland environment while a grass-dominated mixed feeding in a karst environment (Kaiser \& Rössner 2007). These findings provide support for our hypothesis that earliest representatives could have been physiologically qualified to both browse and graze (DeMiguel et al. 2008).

\section{CONCLUSION}

Results gathered from the latest Andegameryx and first Procervulus revealed an important degree of variation of their dental wear features. Despite the fact that only the mixed feeder major dietary category proposed by Hofmann \& Stewart (1972) is represented in the Ramblian localities, species seem to have been significantly versatile in food exploitation.

Our data are concordant with a mixed feeder strategy for the earliest known members of Procervulus, which raise an important evolutionary uncertainty concerning the traditional characterization of first deer as specialised browsers. Instead, these results corroborate the recently proposed hypothesis that first cervids were able to consume a mixture of browse and grass (i.e. facultative mixed feeding; DeMiguel et al. 2008), and therefore, that were originally mixed feeders. Early taxa seem to have been physiologically adapted to feed on a mixed diet, but the morphological expression of this state would have depended on environmental conditions. As Andegameryx also exhibited a mixed dietary strategy, this condition seems to have been not only the ancestral state of Cervidae, but also of other lineages of Pecora ruminants. Important dietary heterogeneity among similarly aged ruminants belonging to the same genus or species corroborates this notion. The much higher proportion of typical browsing signatures in the German localities and the presence of mixed feeding habits in the taxa from Central Spain are probably justifiable as a consequence of the presence of different environments.

In terms of resource utilization, body size results indicate that Andegameryx and Procervulus could have partitioned the available vegetation in Ágreda in terms of height above ground level (vertical habitat stratification). However, ecological segregation was most likely not only achieved through body mass differences. Dental wear clearly evidences that they were not dependent on a limited type of vegetation and, consequently, were able to exploit different food resources. Such generalist dietary strategy could have allowed species to switch from open to closed patches (space partitioning), depending on factors such as food availability or competition (Calandra et al. 2008). Alternatively, Andegameryx and Procervulus could eat many of the same plant species, but often did so at different times of the year (time partitioning). Accordingly, body size difference coupled with an important degree of opportunism in their feeding strategy may have been necessary factors to elude competition in Ágreda. The higher trophic flexibility exhibited by Procervulus could have been a clear advantage to persist to the general increase in aridity that took place during the Middle Miocene (Miocene Climatic Optimum). These data seem to indicate that the extinction of Andegameryx may have not been consequence of the food competition with Procervulus. Further analyses including more extensive material will certainly allow better understand the dietary habits and the paleoecology of the early pecorans in the Early Miocene of Central Spain.

\section{Acknowledgements}

The authors wish to thank all the students and colleagues for their help with the excavations. Field missions were financed and supported by the Government of Aragón (DGA), the Instituto Geológico y 
Minero de España (IGME), the Netherlands Organization for the Advancement of Pure Research (ZWO), the State University of Groningen (The Netherlands) and the Rijksmuseum van Geologie en Mineralogie (Leiden, The Netherlands). We also thank L. Alcalá and E. Espilez (Fundación Conjunto Paleontológico Teruel-Dinópolis) for the access to the specimens from Alto de Ballester 1 that are temporary housed in this institution. At last, we would like to thank Annemarie Ohler (Muséum national d'Histoire naturelle, Paris) and two anonymous reviewers, who gave their help to improve the manuscript. This research was supported by means of projects CGL2011-27343, CGL2011-25754 and CGL2011-19116, CGL2010-21672 and contract JCI-2011-11697 to DDM (Spanish Ministerio de Economía y Competitividad), the Research Group BSCH-UCM 910607 (Universidad Complutense de Madrid) and E05 (Government of Aragón).

\section{REFERENCES}

Aguilar J.-P., Antoine P.-O., Crochet J.-Y., LópezMartínez N., Métais G., Michaux J. \& WelCOMME J. L. 2003. — Les mammifères du Miocène inférieur de Beaulieu (Bouches-du-Rhône, France), comparaison avec Wintershof-West et le problème de la limite MN3/MN4. Coloquios de Paleontología, vol. extr. 1: 1-24.

Anadón P., Sanz-Rubio E., Alcalá L., Alonso-Zarza A. M., Calvo J. P., Orti F. \& Rosell L. 2004. Cuenca de Calatayud, in Vera J. A. (ed.), Geología de España. SGE-IGME, Madrid: 563-565.

AzANZA B. 1993. - Systématique et évolution du genre Procervulus, cervidé (Artiodactyla, Mammalia) du Miocène inférieur d'Europe. Comptes rendus de l'Academie des Sciences de Paris, série II, 316: 717-723.

AZANZA B. 2000. - Los Cervidae (Artiodactyla, Mammalia) del Mioceno de las cuencas del Duero, Tajo, Calatayud-Teruel y Levante. Memorias del Museo Paleontológico de la Universidad de Zaragoza 8: 1-376.

Becker D., Rössner G. E., Picot L. \& Berger J.-P. 2001. - Early Miocene ruminants from Wallenried (USM, Aquitanian/Switzerland): biostratigraphy and paleoecology. Eclogae Geologicae Helvetiae 94: 547-564.

Calandra I., Göhlich U. B. \& Merceron G. 2008. How could sympatric megaherbivores coexist? Example of niche partitioning within a proboscidean community from the Miocene of Europe. Naturwissenschaften 95: 831-838.
Daams R., Freudenthal M. \& Alvarez Sierra M. 1987. - Ramblian; a new stage for continental deposits of Early Miocene age. Geologie en Mijnbouw 65: 297-308.

DeMiguel D., Fortelius M., Azanza B. \& Morales J. 2008. - Ancestral feeding state of ruminants reconsidered: earliest grazing adaptation claims a mixed condition for Cervidae. BMC Evolutionary Biology 8: 1-13.

DeMiguel D., Azanza B. \& Morales J. 2010. Trophic flexibility within the oldest Cervidae lineage to persist through the Miocene Climatic Optimum. Palaeogeography, Palaeoclimatology, Palaeoecology 289: 81-92.

DinERSTEIN E. 1987. — Deer, plant phenology, and succession in the lowland forests in Nepal, in WEMMER C. M. (ed.), Biology and Management of the Cervidae. Smithsonian Institution, Washington: 272-288.

EAdie J. McA., BROEKHOVEN L. \& COlgAN P. 1987. Size ratios and artifacts: Hutchinson's rule revisited. American Naturalist 129: 1-17.

Eronen J. T., Evans A. R., Fortelius M. \& Jernvall J. 2010. - The impact of regional climate on the evolution of mammals: a case study using fossil horses. Evolution 64: 398-408.

Fortelius M. \& SOlounias N. 2000. - Functional characterization of ungulate molars using the abrasionattrition wear gradient: a new method for reconstructing paleodiets. American Museum Novitates 3301: 1-35.

Fortelius M., Eronen J., JernVall J., Liu L., PushKina D., Rinne J., Tesakov A., Vislobokova I., ZHANG Z. \& ZHOU L. 2002. - Fossil mammals resolve regional patterns of Eurasian climate change over 20 million years. Evolutionary Ecology Research 4: 1005-1016.

Gagnon M. \& Chew A. E. 2000. - Dietary preferences in extant African Bovidae. Journal of Mammalogy 81: 490-511.

GAUDRY A. 1877. - Les Enchaînements du monde animal dans les temps géologiques. Mammiferes Tertiaires. Muséum national d'Histoire naturelle, Paris, 293 p.

Gentry A. W., Rössner G. E. \& HeImann P. J. 1999. Suborder Ruminantia, in Rössner G. E. \& HeIsIG K. (eds), The Miocene Land Mammals of Europe. Verlag Dr. Friedrich Pfeil, München: 225-258.

GINSBURG L. 1971. - Un ruminant nouveau des Faluns Miocènes de la Touraine et de l'Anjou. Bulletin $d u$ Muséum national d'Histoire naturelle, Paris, 2e sér., 42: 996-1002.

GinsBURG L. 1985. — Essai de phylogénie des Eupecora (Ruminantia, Artiodactyla, Mammalia). Comptes rendus de l'Academie des Sciences de Paris, série II, 301: 1255-1257.

GinSBURG L. 1999. — Le genre Andegameryx (Artiodactyla, Mammalia). Évolution, position systématique et implications biostratrigraphiques. Bulletin de la 
Société d'histoire naturelle de Toulouse 135: 113-117. GINSBURG L. 2001. — Les faunes de mammiferes terrestres du Miocène moyen des Faluns du bassin de Savignésur-Lathan (France). Geodiversitas 23 (3): 381-394.

Ginsburg L. \& Morales J. 1989. — Les Ruminants du Miocene inferieur de Laugnac (Lot-et-Garonne). Bulletin du Muséum national d'Histoire naturelle, Paris, 4e sér., 4: 201-231.

GinsBURG L., HUIN J. \& LOCHER J.-P. 1985. — Les Artiodactyles sélénodontes du Miocène inférieur des Beilleaux à Savigné-sur-Lathan (Indre-et-Loire). Bulletin du Muséum national d'Histoire naturelle, Paris, 4e sér., 7: 285-303.

Ginsburg L., Morales J. \& Soria D. 1994. - The ruminants (Artiodactyla, Mammalia) from the Lower Miocene of Cetina de Aragón (Province of Zaragoza, Aragón, Spain). Proceedings of the Koninklijke Nederlandse Akademie van Wetenschappen 97 (2): 141-181.

Ginsburg L., Cheneval J., Janvier P., Pouit D. \& SEN S. 2000. - Les vertébrés des sables continentaux d'âge orléanien inférieur (MN3) de Mauvières à Marcilly-sur-Maulne (Indre-et-Loire), La Brosse à Meigné-le-Vicomte (Maine-et-Loire) et Chitenay (Loir-et-Cher). Geodiversitas 22 (4): 597-631.

GORDON I. J. 2003. - Browsing and grazing ruminants: are they different beasts? Forest Ecology and Management 181: 13-21.

HOFMANN R. R. \& STEWART D. R. M. 1972. - Grazer or Browser: a classification based on the stomach structure and feeding habits of east African ruminants. Mammalia 36: 226-240.

Hulbert I. A. R. \& ANDERSEN R. 2001. — Food competition between a large ruminant and a small hindgut fermentor: the case of the roe deer and mountain hare. Oecologia 128: 499-508.

HuTCHINSON G. E. 1959. - Homage to Santa Rosalia, or why are there so many kinds of animals? American Naturalist 93: 145-159.

JANIS C. M. 1990. - Correlation of cranial and dental variables with body size in ungulates and macropoids, in Damuth J. \& MacFadden B. J. (eds), Body Size in Mammalian Paleobiology: Estimation and Biological Implications. Cambridge University Press, Cambridge: 255-299.

JiméneZ-Moreno G., FAuQuette S., SuC J.-P. \& Aziz H. A. 2007a. - Early Miocene repetitive vegetation and climatic changes in the lacustrine deposits of the Rubielos de Mora Basin (Teruel, NE Spain). Palaeogeography, Palaeoclimatology, Palaeoecology 250: 101-113.

JimÉNEZ-MORENO G., AZIZ H. A., RodríGUEZ-TOVAR F. J., PARdo-IgúzQuiza E. \& SuC J.-P. 2007в. — Palynological evidence for astronomical forcing in Early Miocene lacustrine deposits from Rubielos de Mora Basin (NE Spain). Palaeogeography, Palaeoclimatology, Palaeoecology 252: 601-616.

KAISER T. M. \& RÖSSNER G. E. 2007. — Dietary resource partitioning in ruminant communities of Miocene wetland and karst palaeoenvironments in southern Germany. Palaeogeography, Palaeoclimatology, Palaeoecology 252: 424-439.

KHOLER M. 1993. - Skeleton and habitat of recent and fossil ruminants. Münchner Geowissenschaftliche Abhandlungen 25: 1-88.

LEGENDRE S. 1989. — Les communautés de mammiferes du Paléoène (Éocène supérieur et Oligocène) d'Europe occidentale: structures, milieux et évolution. Münchner Geowissenschaftliche Abhandlungen 16: 1-110.

MacFadden B. J. \& Hulbert R. C. JR. 1990. Body size stimates and size distribution of ungulate mammals from the Late Miocene Love Bone Bed of Florida, in Damuth J. \& MacFadden B. J. (eds), Body Size in Mammalian Paleobiology: Estimation and Biological Implications. Cambridge University Press, Cambridge: 337-363.

MaINland I. L. 2003. - Dental microwear in grazing and browsing Gotland sheep (Ovis aries) and its implications for dietary reconstruction. Journal of Archaeological Science 30: 1513-1527.

Merceron G., Viriot L. \& Blondel C. 2004. — Tooth microwear pattern in roe deer (Capreolus capreolus L.) from Chizé (western France) and relation to food composition. Small Ruminant Research 53: 125-132.

Merceron G., De Bonis L., Viriot L. \& Blondel C. 2005. - Dental microwear of fossil bovids from northern Greece: paleoenvironmental conditions in the eastern Mediterranean during the Messinian. Palaeogeography, Palaeoclimatology, Palaeoecology 217: 173-185.

Merceron G., Schulz E., Kordos L., Kaiser T. M. 2007. - Paleoenvironment of Dryopithecus brancoi at Rudaba'nya, Hungary: evidence from dental mesoand micro-wear analyses of large vegetarian mammals. Journal of Human Evolution 53: 331-349.

Montoya P., Peñalver E., Ruiz-Sánchez F. J., Santisteban C., Alcalá L., Belinchón M. \& Lacomba J. I. 1996. - Los yacimientos paleontológicos de la cuenca terciaria continental de Rubielos de Mora (Aragón). Revista Española de Paleontología, no. extr.: 215-224.

Morales J. \& Soria D. 1984. — Los Artiodáctilos del Mioceno inferior de las cuencas centrales de España. Coloquios de Paleontología 39: 51-59.

Morales J., Ginsburg L. \& Soria D. 1986. — Los Bovoidea (Artiodactyla, Mammalia) del Mioceno inferior de España: filogenia y bioestratigrafía. $\mathrm{Pa}$ leontologia i evolució 20: 259-265.

Quiralte V. \& Morales J. 2006. — Los rumiantes (Artiodactyla, Mammalia) del Mioceno inferior de La Encinilla (Colmenar Viejo, Madrid). Estudios Geológicos 62 (1): 515-532.

Rivals F. \& Deniaux B. 2003. - Microwear analysis for investigating the diet of an argali population (Ovis ammon antiqua) of mid-Pleistocene age, Caune de 
l'Arago cave, eastern Pyrenees, France. Palaeogeography, Palaeoclimatology, Palaeoecology 193: 443-455.

Rivals F., MihlBaChler M. C. \& SOlOUNiAS N. $2007 .-$ Effect of ontogenetic-age distribution in fossil samples on the interpretation of ungulate paleodiets using the mesowear method. Journal of Vertebrate Paleontology 27: 763-767.

RÖSSNER G. E. 1995. — Odontologishe und schädelanatomische Untersuchungen an Procervulus (Cervidae, Mammalia). Münchner Geowissenschaftliche Abhandlungen 29: 1-128.

Sanson G. D., Kerr S. A. \& Gross K. A. 2007. — Do silica phytoliths really wear mammalian teeth? Journal of Archaeological Science 34: 526-531.

Schulz E., FahlKe J. M., Merceron G. \& Kaiser T. M. 2007. - Feeding ecology of the Chalicotheriidae (Mammalia, Perissodactyla, Ancyclopoda). Results from dental micro- and mesowear analyses. Verhandlungen des Naturwissenschaftlichen Vereins Hamburg 43: 5-32.

SсотT K. M. 1983. - Prediction of body weight of fossil Artiodactyla. Zoological Journal of the Linnean Society 77: 199-215.

ScotT K. M. 1990. - Postcranial dimensions of ungulates as predictors of body mass, in DAMUTH J. \& MacFadden B. J. (eds), Body Size in Mammalian Paleobiology: Estimation and Biological Implications. Cambridge University Press, Cambridge: 301-336.

Solounias N. \& Moelleken S. M. C. 1992. — Tooth microwear analysis of Eotragus sansaniensis (Mammalia: Ruminantia), one of the oldest known bovids. Journal of Vertebrate Paleontology 12: 113-121.

SOlOUNiAS N. \& MOELleKEN S. M. C. 1994. — Dietary differences between two archaic ruminant species from Sansan, France. Historical Biology 7: 203-220. Solounias N. \& Semprebon G. 2002. - Advances in the reconstruction of ungulate ecomorphology with application to early fossil equids. American Museum Novitates 3366: 1-49.

Solounias N., McGraW W. S., Hayek L.-A. \& WerdeLIN L. 2000. - The paleodiet of the Giraffidae, in Vrba E. S. \& Schaller G. B. (eds.), Antelopes, Deer, and Relatives: Fossil Record, Behavioural Ecology, Systematics and Conservation. Yale University Press, New Heaven: 84-95.

Valli A. M. F. \& Palombo M. R. 2008. - Feeding behaviour of middle-size deer from the Upper Pliocene site of Saint-Vallier (France) inferred by morphological and micro/mesowear analysis. Palaeogeography, Palaeoclimatology, Palaeoecology 257: 106-122.

VAN DAM J. 2006. - Geographic and temporal patterns in the late Neogene (12-3 Ma) aridification of Europe: the use of small mammals as paleoprecipitation proxies. Palaeogeography, Palaeoclimatology, Palaeoecology 238: 190-218.

VAn DER Made J. \& Morales J. 1999. - Aureliachoerus (Suidae, Mammalia) from Ágreda and other Miocene localities of Spain. Geobios 32: 901-914.

VAN VAlKenburgh B. 1990. - Skeletal and dental predictors of body mass in carnivores, in DAMUTH J. \& MacFadden B. J. (eds), Body Size in Mammalian Paleobiology: Estimation and Biological Implications. Cambridge University Press, Cambridge: 181-205.

Williams S. H. \& KaY R. F. 2001. - A comparative test of adaptive explanations for hypsodonty in ungulates and rodents. Journal of Mammalian Evolution 8: 207-29. 